\title{
Study of behavior of cardiac pacemaker batteries capacity in different situations of electro-electronic variations
}

\author{
Oliveira ALO§, Leite FPL§, Santineli CSS§, DelMonaco ADM§, Drigo ES§. \\ $\S$ Centro Universitário das Américas, São Paulo, Brasil.
}

\begin{abstract}
The research analyzes issues related to events that originate the behavior of a pacemaker battery in certain electro-electronic variations. Based on idea that pacemaker has the purpose of supporting the heart rate with electrical stimuli, the existence of errors in equipment's battery can lead to reduced autonomy and restricted failures that cause it to malfunction. The research process is based on bibliographic reviews and objective is to investigate cause of failure and explain in a technical way how this error can be minimized in order to reduce likelihood of these undesirable events in the equipment's operation.
\end{abstract}

Key words. Pacemaker; drums; failures; heart rate; autonomy.

Introduction. Pacemaker is a device used in medicine and aims to control heartbeat through an electrical stimulus that is boosted when the number of beats in a certain time interval is altered.

Pacemaker is an electronic device composed of a programmable generator of electrical pulses (the pacemaker box) with one, two or even three electrodes. Electrodes are conductive terminations that conduct electrical impulses generated by pacemaker to the heart. Each electrical impulse generated by the pacemaker promotes contraction and relaxation of the heart. Thus, heart rate can change according to the programming performed on the pacemaker.1

It supplements a slow heart rate, helping to control abnormalities. In addition, the mechanism makes sure that ventricles contract normally, contraction of atria, the upper chambers of heart, pumps blood into the ventricles, lower chambers of heart, so this combination is called heartbeat, with normalized contraction avoided. if problems like atrial fibrillation, occurring when the atria tremble instead of hitting. 5

Although, pacemaker is a relatively safe electronic device, failures and possible damage can happen, just like any electronic device. This research project deals with how the battery of a cardiac pacemaker and its components can present electro-electronic variations.

In general, it is essential to know the functioning of the system that makes up the pacemaker, in order to minimize any errors and guarantee the patient's well-being.

Methods. The organization and structuring of project consists of stages with an expected duration of 12 months. Project will be subjected to tests and analyzes in its practical and theoretical aspect in relation to problems addressed and proposed objectives. Data obtained tend to enable a better understanding of pacemaker system and the cause of errors that compromise functioning of battery in different electro-electronic variations. In this way, a clear and general purpose for the research is obtained.

To obtain the essential data, it is necessary to collect and analyze the data through consultations in academic materials that address anatomy, analog electronics, digital electronics and instrumentation.

For the development of scientific initiation project, it was necessary to use an electronic circuit simulation application, to collect data and signals related to the operation and eventual 
visualization of circuit failures that cause a decrease in the pacemaker battery autonomy.

Results and discussion. Pacemaker consists of an electronic circuit with a control function and a pulse generator, electrodes and a battery. Battery supplies the circuit and electrodes connect generator to heart and are responsible for sending electrical impulses to heart. With an abnormal heart rhythm, the pacemaker kicks in so that the pulse-generating circuit forwards electrical impulses to the heart.5

Pacemaker configuration comes down to two main ones, namely rate of demand and rate of response to rates. The demand pacemaker monitors cardiac rhythm, sending electrical impulses to heart, whereas the rhythm pacemaker speeds up or decreases heart rate, monitoring the rate of sinus node, breathing, blood temperature and other factors to determine leveling of the heart rate activity.

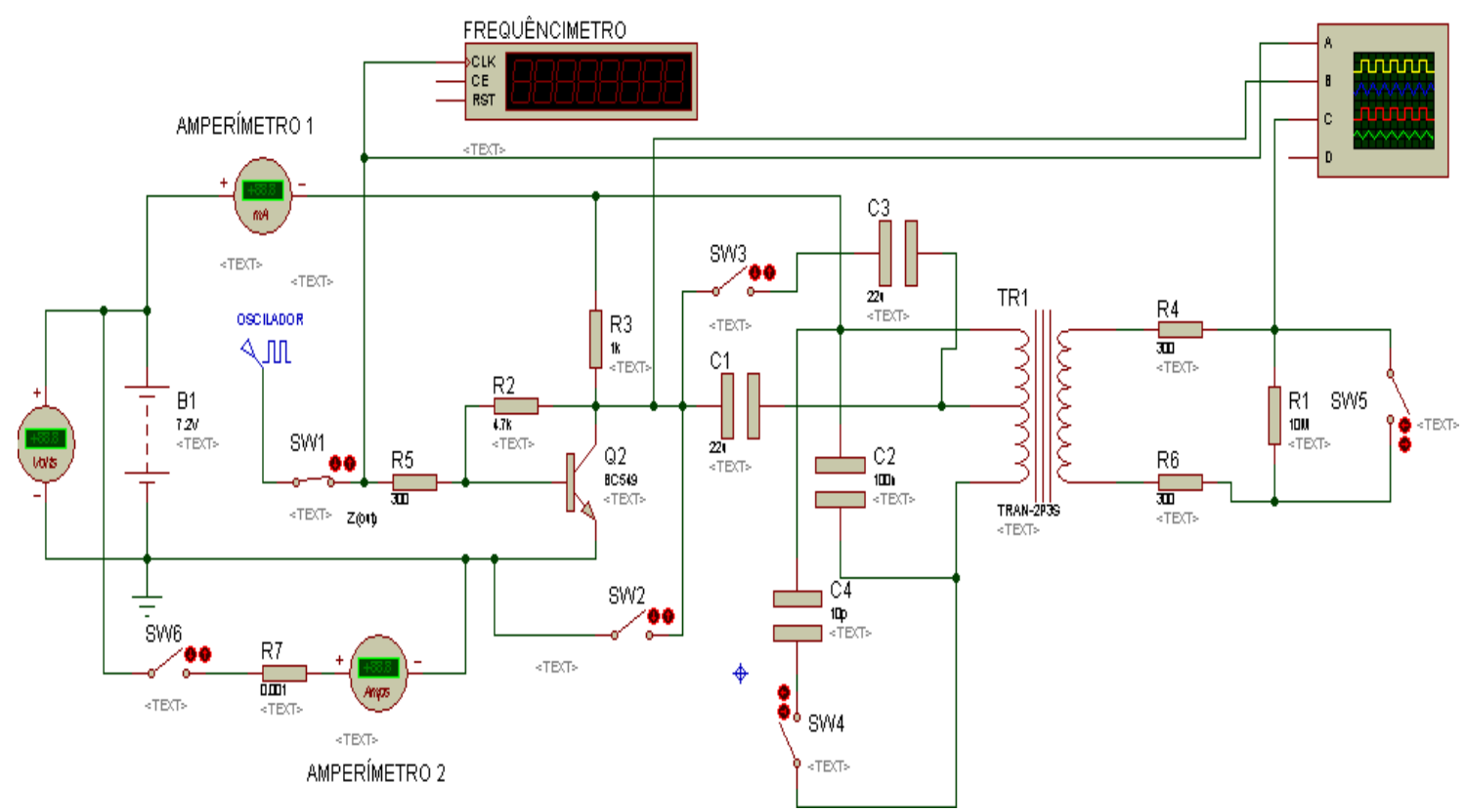

Figure 1: represents a cardiac pacemaker simulator. The selector switches have the function of simulating normal situations and conditions of defects in the device.

Source: Authorship

In the tables below, the description of switches and resistors for simulation of defects in circuit are:

R5: oscillator output impedance;

SW1: sensor that connects pacemaker;

SW2: short or defect in oscillator output;

SW3: defect in coupling capacitor at the output of the oscillator;

SW4: defect in capacitor for the time base at input of transformer;

SW5: short circuit in electrodes;

SW6: short circuit at pacemaker input;

mAp: peak current ammeter;

A1 (mA): ammeter average current 1;

A2 (mA): average current ammeter 2; 
TAS Journal, vol. 5, n. 1, p. 45-55.

ISSN 2595-1521

MARCH 2021

fabiellepereira258@gmail.com

V: voltmeter;

$\mathrm{Hz}$ : frequency meter (monitors the frequency of generated impulses).

During the cardiac pacemaker simulation, different types of tests were introduced, thus finding flaws in certain keys.

Table 1 - Description of cardiac pacemaker defects

\begin{tabular}{|c|c|}
\hline Open Keys & Error description \\
\hline SW1 & SIMULATES THE SENSOR THAT ACTIVATES PACEMAKER \\
\hline SW2 & $\begin{array}{l}\text { SIMULATES A SHORT-CIRCUIT AT OUTPUT OF THE OSCILLATOR } \\
\text { (PROBABLE DAMAGE IN OUTPUT TRANSISTOR OF THE } \\
\text { OSCILLATOR) THAT MAKES PACEMAKER NO MORE ABLE TO } \\
\text { GENERATE PULSES AND THEREFORE IT DOES NOT WORK AT } \\
\text { REQUIRED TIME. IN THIS CASE THERE IS A RISK TO PATIENT'S } \\
\text { HEALTH. }\end{array}$ \\
\hline SW3 & $\begin{array}{l}\text { SHORT-CIRCUIT IN COUPLING CAPACITOR, AT OUTPUT OF THE } \\
\text { OSCILLATOR. INJECTS DC CURRENT IN THE TRANSFORMER, } \\
\text { SATURATING IT AND DISCARACTERIZING PACEMAKER PULSES. } \\
\text { INCREASING THE WRISTING AMPLITUDE IS ONE OF CONSEQUENCES } \\
\text { AND THIS MAY CARE RISK TO PATIENT'S HEALTH. }\end{array}$ \\
\hline SW4 & $\begin{array}{l}\text { CAPACITOR DEFECT THAT DEFINES POWER CIRCUIT INPUT } \\
\text { IMPEDANCE. IF THERE IS ONLY AN INCREASE IN CAPACITANCE } \\
\text { THERE ARE NO PROBLEMS, BUT IF THERE IS A SUDDEN FALL, } \\
\text { TRYING TO ZERO, POWER STEP MAY STOP WORKING AND } \\
\text { PACEMAKER ALSO. }\end{array}$ \\
\hline SW5 & $\begin{array}{l}\text { SHORT-CIRCUIT ON ELECTRODES. INTERRUPT FUNCTIONING OF } \\
\text { PACEMAKER AND TAKES RISKS TO THE PATIENT. CONSUMPTION } \\
\text { CHAIN DOES NOT INCREASE AND OTHERWISE FALLS, DUE TO } \\
\text { ACTION OF GALVANIC INSULATION PERFORMED BY TRANSFORMER } \\
\text { THAT ISOLATES PULSE CONTROL CIRCUIT FROM PULSE POWER } \\
\text { CIRCUIT. }\end{array}$ \\
\hline SW6 & $\begin{array}{l}\text { SHORT-CIRCUIT AT ENTRANCE MARCAPASSO IS WORST POSSIBLE } \\
\text { SITUATION, BECAUSE IN THIS CASE APPLIANCE DOES NOT WORK } \\
\text { AND THE BATTERY IS QUICKLY CONSUMED. IN THIS CASE THERE IS } \\
\text { A RISK OF FIRE AND PATIENT'S HEALTH. }\end{array}$ \\
\hline $\mathbf{R 5}$ & $\begin{array}{l}\text { VARIATION IN OUTPUT IMPEDANCE OF OSCILLATOR MAY } \\
\text { COMPROMISE FUNCTIONING OF PACEMAKER, INTERFERING ITS } \\
\text { FUNCTIONING AND THEREFORE IN INCREASING IN BATTERY } \\
\text { CURRENT CONSUMPTION. }\end{array}$ \\
\hline
\end{tabular}


Table 2: Representation of operation modes of switches in each simulation

\begin{tabular}{|c|c|c|c|c|c|}
\hline \multicolumn{6}{|c|}{ SW6 On simulations } \\
\hline KEYS & SW1 & SW2 & SW3 & SW4 & SW5 \\
\hline \multirow[b]{2}{*}{ TABLES } & $\begin{array}{l}\text { On: } \\
\text { SW1; } \\
\text { SW6. }\end{array}$ & $\begin{array}{l}\text { On: } \\
\text { SW1; } \\
\text { SW2; } \\
\text { SW6. }\end{array}$ & $\begin{array}{l}\text { On: } \\
\text { SW1; } \\
\text { SW3; } \\
\text { SW6. }\end{array}$ & $\begin{array}{l}\text { On: } \\
\text { SW1; } \\
\text { SW4; } \\
\text { SW6. }\end{array}$ & $\begin{array}{l}\text { On: } \\
\text { SW1; } \\
\text { SW5; } \\
\text { SW6. }\end{array}$ \\
\hline & $\begin{array}{c}\text { Off: } \\
\text { SW2; } \\
\text { SW3; } \\
\text { SW4; } \\
\text { SW5. }\end{array}$ & $\begin{array}{l}\text { Off: } \\
\text { SW3; } \\
\text { SW4; } \\
\text { SW5. }\end{array}$ & $\begin{array}{l}\text { Off: } \\
\text { SW2; } \\
\text { SW4; } \\
\text { SW5. }\end{array}$ & $\begin{array}{l}\text { Off: } \\
\text { SW2; } \\
\text { SW3; } \\
\text { SW5. }\end{array}$ & $\begin{array}{c}\text { Off: } \\
\text { SW2; } \\
\text { SW3; } \\
\text { SW4. }\end{array}$ \\
\hline \multicolumn{6}{|c|}{ SW6 Off simulations } \\
\hline KEYS & SW1 & SW2 & SW3 & SW4 & SW5 \\
\hline \multirow[b]{2}{*}{ TABLES } & $\begin{array}{l}\text { On: } \\
\text { SW1. }\end{array}$ & $\begin{array}{l}\text { On: } \\
\text { SW1; } \\
\text { SW2. }\end{array}$ & $\begin{array}{l}\text { On: } \\
\text { SW1; } \\
\text { SW3. }\end{array}$ & $\begin{array}{l}\text { On: } \\
\text { SW1; } \\
\text { SW4. }\end{array}$ & $\begin{array}{l}\text { On: } \\
\text { SW1; } \\
\text { SW5. }\end{array}$ \\
\hline & $\begin{array}{c}\text { Off: } \\
\text { SW2; } \\
\text { SW3; } \\
\text { SW4; } \\
\text { SW5; } \\
\text { SW6. }\end{array}$ & $\begin{array}{c}\text { Off: } \\
\text { SW3; } \\
\text { SW4; } \\
\text { SW5; } \\
\text { SW6. }\end{array}$ & $\begin{array}{l}\text { Off: } \\
\text { SW2; } \\
\text { SW4; } \\
\text { SW5; } \\
\text { SW6. }\end{array}$ & $\begin{array}{c}\text { Off: } \\
\text { SW2; } \\
\text { SW3; } \\
\text { SW5; } \\
\text { SW6. }\end{array}$ & $\begin{array}{l}\text { Off: } \\
\text { SW2; } \\
\text { SW3; } \\
\text { SW4; } \\
\text { SW6. }\end{array}$ \\
\hline
\end{tabular}

In each of simulations, tests were performed with only one switch on at a time, with exception of the SW1 switch, since it starts the pacemaker operation. In this case, this key remained on during all simulations.

Correction factor. In order to adjust the data measured in the simulated circuit, with the usual pacemaker current informed in (3), it is necessary to use a correction factor, informed in equation (1):

$i_{(\text {simulated corrected })}=0,12\left[i_{(\text {measure })}\right]$

Where: 0.12 corresponds to current correction factor; 
TAS Journal, vol. 5, n. 1, p. 45-55.

ISSN 2595-1521

MARCH 2021

fabiellepereira258@gmail.com

Table 3: Simulation using $300 \mathrm{Ohm}$ resistor and SW6 switch connected

\begin{tabular}{|c|c|c|c|c|c|}
\hline \multicolumn{6}{|c|}{ Test using R5 $300 \Omega$ and Sw6 connected } \\
\hline Keys & $(\mathbf{m A p})$ & $\mathbf{A 1}(\mathbf{m A})$ & $\mathbf{A} 2(\mathbf{m A})$ & $(\mathrm{V})$ & $(\mathbf{H z})$ \\
\hline SW1 & 0,2544 & 0,0012 & 7,788 & 0,71 & 60 \\
\hline SW2 & 0,1104 & 0,0852 & 7,788 & 0,71 & 60 \\
\hline SW3 & 0,3408 & 0,0012 & 7,788 & 0,71 & 60 \\
\hline SW4 & 0,2592 & 0,0012 & 7,788 & 0,71 & 60 \\
\hline SW5 & 0,2052 & 0,0012 & 7,788 & 0,71 & 60 \\
\hline
\end{tabular}

In the test with the SW6 switched on and 300 o, the circuit showed an initial behavior in a transient peak current regime, however there was a progressive drop and stabilized in a permanent regime around the value presented in its average current.

Table 4: Simulation using $300 \mathrm{ohm}$ resistor and SW6 switch off

\begin{tabular}{|ccccc|c|}
\hline \multicolumn{7}{|c|}{ Test using R5 300 $\mathbf{\Omega}$ and Sw6 off } \\
\hline K & $(\mathbf{m A p})$ & $\mathbf{A 1}(\mathbf{m A})$ & $\mathbf{A 2}(\mathbf{m A})$ & $(\mathbf{V})$ & $(\mathbf{H z})$ \\
\hline SW1 & 1,932 & 0,012 & 0 & 0,71 & 60 \\
$\mathbf{S W 2}$ & 0,87 & 0,864 & 0 & 0,71 & 60 \\
SW3 & 2,184 & 0,0132 & 0 & 0,71 & 60 \\
SW4 & 1,944 & 0,012 & 0 & 0,71 & 60 \\
SW5 & 1,392 & 0,0084 & 0 & 0,71 & 60 \\
\hline $\begin{array}{l}\text { Observed behavior: The circuit remained in a transient (peak) situation until it gradually stabilized } \\
\text { slowly, reaching its permanent regime. }\end{array}$
\end{tabular}


In the test with the SW6 switched off (normal operating situation) and $300 \Omega$, current remained longer in transient regime (peak), after that it showed a progressive drop and stabilized around its average current.

Table 5: Simulation using $30 \mathrm{ohm}$ resistor and SW6 switch off.

\begin{tabular}{|c|c|c|c|c|c|}
\hline \multicolumn{6}{|c|}{ Test using R5 $30 \Omega$ and Sw6 off } \\
\hline Keys & (mAp) & A1 (mA) & $\mathrm{A} 2(\mathrm{~mA})$ & (V) & $(\mathrm{Hz})$ \\
\hline SW1 & 1,992 & 0,0132 & 0 & 0,71 & 60 \\
\hline SW2 & 5,652 & 0,864 & 0 & 0,71 & 60 \\
\hline SW3 & 2,28 & 0,0144 & 0 & 0,71 & 60 \\
\hline SW4 & 2,04 & 0,0132 & 0 & 0,71 & 60 \\
\hline SW5 & 1,488 & 0,0096 & 0 & 0,71 & 60 \\
\hline
\end{tabular}

In test with the SW6 off and R5 with a value of $30 \Omega$, simulating a drop in oscillator output impedance, the current started again in its transient regime gradually decreased until it stabilized in its permanent regime around its average current, shown in the aforementioned table 3.

Table 6: Simulation using $30 \mathrm{ohm}$ resistor and SW6 switch connected

\begin{tabular}{|c|c|c|c|c|c|}
\hline \multicolumn{6}{|c|}{ Test using R5 $30 \Omega$ and Sw6 off } \\
\hline Keys & $(\mathbf{m A p})$ & A1 (mA) & $\mathrm{A} 2(\mathrm{~mA})$ & $(\mathrm{V})$ & $(\mathbf{H z})$ \\
\hline SW1 & 0,5568 & 0,0012 & 7,788 & 0,71 & 60 \\
\hline SW2 & 0,5592 & 0,0012 & 7,788 & 0,71 & 60 \\
\hline SW3 & 0,5568 & 0,0012 & 7,788 & 0,71 & 60 \\
\hline SW4 & 0,5592 & 0,0012 & 7,788 & 0,71 & 60 \\
\hline SW5 & 0,552 & 0,0012 & 7,788 & 0,71 & 60 \\
\hline
\end{tabular}


In SW6 test connected and $30 \Omega$, the current started at a low level and subsequently increased gradually until it stabilized in its steady state value, as shown in Table 4.

Table 7: Simulation using $3000 \mathrm{ohm}$ resistor and SW6 switch connected

\begin{tabular}{|c|c|c|c|c|c|}
\hline \multicolumn{6}{|c|}{ Test using R5 $3000 \Omega$ and Sw6 connected } \\
\hline Keys & $(\mathbf{m A p})$ & $\mathbf{A 1}(\mathbf{m A})$ & $\mathbf{A} 2(\mathbf{m A})$ & $(\mathrm{V})$ & $(\mathbf{H z})$ \\
\hline SW1 & 0,2064 & 0 & 7,788 & 0,71 & 60 \\
\hline SW2 & 0,0972 & 0,5448 & 7,788 & 0,71 & 60 \\
\hline SW3 & 0,2316 & 0 & 7,788 & 0,71 & 60 \\
\hline SW4 & 0,2088 & 0 & 7,788 & 0,71 & 60 \\
\hline SW5 & 0,1584 & 0 & 7,788 & 0,71 & 60 \\
\hline
\end{tabular}

In test with $\mathrm{SW} 6$ on and $3 \mathrm{k} \Omega$, a sudden increase in oscillator output impedance is simulated. In this test the current starts with a gradual and accelerated increase, until reaching a high value. In a second instant after that fell again and stabilized around its average current (permanent regime).

Table 8: Simulation using 3000 ohm resistor and sw6 switch off.

\begin{tabular}{|c|c|c|c|c|c|}
\hline \multicolumn{6}{|c|}{ Test using R5 $3000 \Omega$ and Sw6 off } \\
\hline Keys & $(\mathbf{m A p})$ & $\mathbf{A} 1(\mathbf{m A})$ & $\mathbf{A} 2(\mathbf{m A})$ & $(\mathbf{V})$ & $(\mathbf{H z})$ \\
\hline SW1 & 1,74 & 0,0072 & 0 & 0,71 & 60 \\
\hline SW2 & 2,88 & 0,864 & 0 & 0,71 & 60 \\
\hline SW3 & 1,728 & 0,0072 & 0 & 0,71 & 60 \\
\hline SW4 & 1,74 & 0,0072 & 0 & 0,71 & 60 \\
\hline SW5 & 1,32 & 0,006 & 0 & 0,71 & 60 \\
\hline
\end{tabular}


In test with SW6 off and $3 \mathrm{k} \Omega$, a sudden increase in oscillator output impedance is simulated. In this test the current starts with a gradual and accelerated increase, until reaching a high value. In a second instant after that, it fell again and stabilized around its average current (permanent regime).

Parameters of pacemaker battery. The pacemaker with older circuits generates pulses $1 \mathrm{~ms}$ wide. Each pulse has a current amplitude of $10 \mathrm{~mA}$ and a repetition rate of $60 \mathrm{bpm}$. The average current consumption of circuit in these conditions was about $12 \mu \mathrm{A}$. The battery for this supply consisted of ten mercury-zinc cells. Under these normal operating conditions, the estimated battery life was five years. 3

Battery life varies according to the condition of each cardiac pathology, since pacemaker can have different types of programming that will be linked to frequency that device is used.1 Durability of pacemaker is determined by period between implant and detection of the end of life of pulse generator, one of the determining factors is battery's used load capacity and energy consumption.6

Since electrical impedance is opposition that an electrical circuit makes when current is subjected to a voltage, this impedance is the result of the total opposite force, consisting of two vector components, resistance and reactance. 2

Therefore, as the impedance changes, the circuit behaves in different ways, and directly affects the pacemaker's operating current levels.

It is worth mentioning that there are current patterns in certain errors, such as the SW6, which is a short circuit at pacemaker input, when turned off, prevented current flow from the ammeter 2.

Autonomy Correction Factor. The battery autonomy correction factor serves to adjust the autonomy time reported in (3), with the currents measured via the simulator and corrected through the current correction factor. Thus, there is a perception of the pacemaker battery's autonomy, depending on the type of defect in the device, described in table 1. For this study, only the highest current values shown in tables 3 to 8 are used.

To maintain proportionality, the following system is used:

$$
\begin{array}{lll}
\text { Current }_{(\text {standard) }} & \rightarrow & \text { Autonomy (years) }_{(\text {toviw) }}
\end{array}
$$

Performing the product on the lines, we find equation (2) that informs the battery's autonomy in years, when subjected to a defect that causes the operation with current demand (corrected simulated), obtained through equation (1):

$$
\text { Autonomy }(\text { previw })=\overline{\left.60.10^{-6 \text { Current }_{(\text {simulated })}[\text { years }}\right]}
$$

If the conversion of time into days is necessary, for a better visualization of the autonomy, just use equation (3): 
Simulation of battery life for the most critical defect conditions. The most critical and reported defect conditions in tables using tables 3 and 4 as an example are:

Defect Condition Table 3 for A2:

Configuration of the SW1 simulation (sensor that activates the pacemaker):

$\mathrm{R} 5=300 \Omega$,

SW1 (on),

SW6 (on) and other switches off $\mathrm{i}$ (measure) $=64.9 \mathrm{~mA}$

$\mathrm{i}($ corrected simulation $)=7788 \mu \mathrm{A}$

Autonomy $=7.70 \times 10-3$ years Autonomy $=2$ days

The rest of the A2 (connected) values are equivalent.

Conclusion: This defect abruptly reduces battery life and may pose an imminent risk to patient's health.

Defect Condition Table 4 for A1:

Configuration of the SW1 simulation (sensor that activates the pacemaker):

$\mathrm{R} 5=300 \Omega$,

SW1 (on),

SW6 (off) and other switches off i (measure) $=0.10 \mathrm{~mA}$

$\mathrm{i}($ corrected simulation $)=12 \mu \mathrm{A}$

Autonomy $=5$ years

Autonomy $=1826$ days

Conclusion: Even though there is no impact on autonomy, the injection of DC current in the power stage changes the characteristics of the waveforms in the electrode and can pose a risk to patient's health.

\section{SW2 simulation configuration (short or defect in the oscillator output):}

$\mathrm{R} 5=300 \Omega$,

SW1 (on),

SW2 (on),

SW6 (off) and other switches off

$\mathrm{i}($ measure $)=7.20 \mathrm{~mA}$

$\mathrm{i}($ corrected simulation $)=864 \mu \mathrm{A}$

Autonomy $=0.069$ years

Autonomy $=25.34$ days

Conclusion: This defect abruptly reduces battery life and may pose an imminent risk to patient's health.

SW3 simulation configuration (defect in the coupling capacitor at the oscillator output):

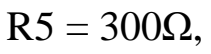

SW1 (on),

SW3 (on),

SW6 (off) and other switches off 
$\mathrm{i}($ measure $)=0.11 \mathrm{~mA}$

$\mathrm{i}($ corrected simulation $)=13.2 \mu \mathrm{A}$

Autonomy $=4.54$ years

Autonomy $=1659$ days

Conclusion: This changes the behavior of the generated pulses and may bring an imminent risk to patient's health.

Configuration of the SW4 simulation (defect in capacitor for time base at transformer input):

$\mathrm{R} 5=300 \Omega$,

SW1 (on),

SW4 (on),

SW6 (off) and other switches off

$\mathrm{i}$ (measure) $=0.10 \mathrm{~mA}$

$\mathrm{i}($ corrected simulation $)=12 \mu \mathrm{A}$

Autonomy $=5$ years

Autonomy $=1826$ days

Conclusion: Even though there is no impact on autonomy, the injection of DC current in power stage changes the characteristics of the waveforms in the electrode and can pose a risk to patient's health.

SW5 simulation configuration: (short circuit on the electrodes):

$\mathrm{R} 5=300 \Omega$,

SW1 (on),

SW5 (on),

SW6 (off) and other switches off

$\mathrm{i}$ (measure) $=0.07 \mathrm{~mA}$

$\mathrm{i}($ corrected simulation $)=8.4 \mu \mathrm{A}$ Autonomy $=7.14$ years Autonomy $=2607$ days

Conclusion: This, despite not reducing battery life, due to galvanic coupling provided by the transformer, can still imply an imminent risk to patient's health.

Discussion. Cardiac pacemaker, when subjected to different electro-electronic variations, becomes subject to several failures that cause a considerable loss in battery life. Such defects were addressed from a simulator, where a circuit was simulated with operating characteristics similar to that of a real pacemaker.

It was identified in the study how each defect can compromise functioning of pacemaker and how the impact of this defect can be related to the battery's autonomy. For this, keys were introduced in simulated circuit, with each key having the function of simulating a defect in pacemaker.

The first switch, indicated as SW1, detects sensor that triggers operation of pacemaker, but when SW6 turns on, it is understood that there was a short circuit at input of the device and in this case all current in the circuit is drained to the ground. This condition is due to the low internal resistance of battery.

When electrical stimulus is not produced or transmitted to myocardium by the device, disturbances in stimulation of the mechanism occur. The causes can occur due to detachment of cable, electrolytic alteration, discharging of the battery or antiarrhythmic treatment. 4 
Thus, simulated defects can not only compromise battery life or its autonomy, but also entail imminent risks to patient's health.

Conclusion. Simulations of cardiac pacemaker failures can result in a considerable decrease in battery longevity. The same battery that under normal operating conditions tends to last around 5 years, with the faults simulated and described, have in some situations a high consumption rate and, consequently, a reduction in its load and useful life. Thus, it is concluded that bibliographic review and research reached significant data to understand the functioning of a pacemaker and, consequently, the possible failures that may impact damage to circuit and battery.

\section{References.}

(1) Clínica de Arritmia e Marcapasso. Implante de Marcapasso. Disponível em: http://www.clinicaritmo.com.br/tratamentos/implante-de-marcapasso/. Acesso em $22 \mathrm{de}$ setembro de 2019.

(2) GOMEZ, M.L. What is impedance in electric circuits and what is its importance?. Commercial Applications, Electrical Projects. Bright Hub Engineering. Disponível em: $\quad$ https://www.brighthubengineering.com/commercialelectrical- applications/47374-electrical-impedance-explained/. Acesso em 22 de fevereiro de 2020 .

(3) Haddad, Sandro; Houben, Richard; Serdijn, Wouter. The history of cardiac pacemakers: an electronics perspective. 2006. IEEE Engineering in Medicine and Biology Magazine. 25. 38-48. Disponível em:

https://www.researchgate.net/publication/263087017_The_history_of_cardiac_pace makers_an_electronics_perspective. Acesso em: 10 de agosto de 2020.

(4) MYEKG. PROBLEMAS COM A ESTIMULAÇÃO DO MARCAPASSO. Disponível em: $\quad$ https://pt.my-ekg.com/marcapasso-ecg/alteracoes-marcapasso-ecg.html. Acesso em 03 de Janeiro de 2020.

(5) National Heart, Lung, and Blood Institute. PACEMAKERS. HEALTH TOPICS PACEMAKERS. Disponivel em: https://www.nhlbi.nih.gov/health-topics/pacemakers. Acesso em 03 de janeiro de 2020.

(6) RIBEIRO, A.L.P; RINCON L.G.; et al. Aumento da Longevidade do Marcapasso Através de Reprogramação. Subutilização e Benefícios. ArqBrasCardiol, volume 76 $\left(n^{\circ} \quad 6\right), \quad 437-40, \quad 2001 . \quad$ Disponível em: http://publicacoes.cardiol.br/abc/2001/7606/7606001.pdf. Acesso em 20 de setembro de 2020.

(7) TAVARES, L. Marcapasso regula frequência cardíaca mínima do coração e aum enta longevidade; $\quad$ Minhavida. $2013 . \quad$ Disponível em: https://www.minhavida.com.br/saude/galerias/16068-marca- passo-regula-frequenciacardiaca-minima-do-coracao-e-aumenta-longevidade. Acesso em 24 de setembro de 2019. 